\title{
Cloud occurrence and cloud properties in Ecuador
}

\author{
Jörg Bendix*, Rütger Rollenbeck, Dietrich Göttlicher, Jan Cermak
}

Faculty of Geography, Laboratory for Climatology and Remote Sensing (LCRS), University of Marburg, Deutschhausstr. 10, 35032 Marburg, Germany

\begin{abstract}
We used a 3 yr data set of NOAA-AVHRR (Advanced Very High Resolution Radiometer) imagery to investigate cloud frequency, cloud-top height and cloud liquid water path for the Ecuadorean area, with special reference to a specific region in the Andes of southern Ecuador. In general, the seasonal cycle of cloudiness is significantly correlated to the spatial occurrence of the rainy seasons. However, we found that the complex topography of the Andes with dynamic effects at the windward and lee sides, as well as thermal breeze-systems, cause a specific spatial structure of cloud frequency and cloud properties. For instance, the eastern Andean slopes are mainly affected by a strong dynamic barrage effect of the easterlies, where a line of high cloud frequency occurs in the area of the Andes-occurring system (AOS) rain band. Average cloud-top height reveals a clear division between the Pacific area west of the western Cordillera chain, characterised by lower and more stratiform clouds, and the eastern parts of the country where an increase in average cloud-top height towards the Amazon indicates an intensification of convective cloud formation processes. This corresponds with the higher amounts of cloud liquid path over the Amazon, which illustrates that the cloud water cycle is more intensive in comparison to the Ecuadorian coastal plains.
\end{abstract}

KEY WORDS: Ecuador $\cdot$ Clouds $\cdot$ NOAA-AVHRR

Resale or republication not permitted without written consent of the publishe

\section{INTRODUCTION}

Stephens (2005) emphasizes the key role of clouds in the climate system, and underlines the importance of proper information on cloud dynamics for climate change research, due to multiple feedback effects with other meteorological elements such as air temperature, radiation or water budget. He also stresses that the spatio-temporal knowledge of cloud dynamics is relatively poor because of difficulties in ground-based observation and the poor performance of GCMs and numerical weather prediction (NWP) models in the simulation of clouds. This is the result of the simplified embedded cloud parameterization schemes which are hard to evaluate with current global observations. Deficiencies of climatic and cloud information are particularly marked in tropical high mountain areas (Barry 1992). Beyond the importance of cloud observations for climate change research and weather forecasting, clouds are also important for the terrestrial hydrological cycle, especially in tropical high mountain areas. Bruijnzeel (2001) recently highlighted the important contribution of cloud water deposition on vegetation of tropical montane cloud forests (especially in the Andes) to the regional water resources. This was confirmed locally by investigations of rainfall interception in a tropical montane forest of southern Ecuador (Fleischbein et al. 2005), the central study area of the present study. Additionally, clouds play an important role in plant ecology, mainly due to modifications of the radiation balance (for example, heat, UV-B and water stress by high transpiration rates in the absence of clouds) (e.g. Alados et al. 2000). Some authors demonstrated that enhanced UV-B intensities during clear sky conditions decrease and advance or delay (depending on species) the time of flowering (e.g. Caldwell et al. 1998). Wright et al. (1999) found that in a wet tropical forest flowering and fruit production are synchronized with drought periods and sunny conditions. They stated that the absorption of photosynthetically active radiation (PAR) by clouds in the wet season limits the reproduction potential due to the low accumulation of resources through photosynthesis. Hamann (2004) showed that nearly all canopy tree 
species in a submontane rain forest flowered during the peak of solar irradiance which was mainly a function of cloud cover.

Satellite data are commonly used to overcome the limits of ground-based observations and models for the elaboration of cloud climatologies and weather/climate change forecasts. Global and regional cloud climatologies have been derived from comprehensive data sets of geostationary and polar orbiting systems, underlining the high potential of satellite imagery for cloud observations from space (e.g. International Satellite Cloud Climatology Project [ISCCP], cf. Schiffer \& Rossow 1983, Rossow et al. 1985, Kästner \& Kriebel 2001, Bendix 2002). New opportunities for cloud studies (especially regarding the investigation of cloud properties) have been opened up by novel technologies such as satellite-borne cloud radars (e.g. the Cloudsat mission, Stephens et al. 2002). However, the spatial resolution of the global data sets currently available (e.g. ISCCP) is too low to register local differences of cloudiness especially in a complex topography such as the Ecuadorian Andes.

Some studies on the climate of Ecuador give an overview of climatic zones (Landívar 1977, 1989, Richter 2003) or examine the diurnal and seasonal course of wind velocity in the high Andes of Ecuador (Endlicher 1982). Most studies describe the seasonal variability of temperature and precipitation (Zimmerschied 1958, Bendix \& Lauer 1992, Vuille et al. 2000, Sklenár \& Lægaard 2003) or focus on the impact of the El Niño phenomenon on spatio-temporal patterns of rainfall (Schütte 1968, Bendix \& Bendix 1998, Rossel et al. 1998, Bendix 1999, 2000, Gasparri et al. 1999, Bendix et al. 2003a). Only a few studies include information on cloudiness. Bendix \& Lauer (1992) used data of the meteorological station network and low resolution Geostationary Operational Environmental Satellite (GOES) Analogue Picture Transmission (APT) images to elaborate a dynamic climatology of Ecuador. However, no detailed analysis of cloudiness could be performed for Ecuador due to the low spatial and temporal resolutions of the GOES-APT imagery available. Bendix \& Rafiqpoor (2001) examined the climate of the Paramo de Papallacta (including station data of cloudiness for the village of Papallacta) in the eastern Cordillera of Central Ecuador with special reference to the terrain height-dependent development of soil temperatures.

In conclusion, no high resolution analysis of cloudiness and cloud properties in Ecuador exists up to now. Hence, the aim of the present study is to examine cloud occurrence and the spatial distribution of cloud properties (cloud-top height, cloud liquid water path [LWP]) for Ecuador based on data of the AVHRR (Advanced Very High Resolution Radiometer) aboard the NOAA satellite series. The study also focusses on specific sub- regions of southern Ecuador because the work was performed as part of a joint ecological research project (Beck \& Müller-Hohenstein 2001) situated in this area.

\section{STUDY AREA, DATA AND METHODS}

The main study area and relevant subsets are presented in Fig. 1. The investigation covered Ecuador and adjacent areas (Fig. 1a). Special consideration is given to the Andes of southern Ecuador, the core site of the ecological special research group 402 (FOR 402) of the German Research Council (DFG). The wider study area (Fig. 1b) ranges from the dry inter-Andean basin at Catamayo in the west to the main watershed (Cordillera Oriental de los Andes) with altitudes up to $\sim 3600 \mathrm{~m}$ a.s.l. in the center and the eastern Andean slopes and foothills in the east (Fig. 1b). The inner study site comprises the Reserva Biósfera de San Francisco in the vicinity of the ECSF research station (Estación Científica de San Francisco, latitude: $3^{\circ} 58^{\prime} 18^{\prime \prime} \mathrm{S}$, longitude: $79^{\circ} 4^{\prime} 45^{\prime \prime} \mathrm{W}$, altitude: $1860 \mathrm{~m}$ a.s.l.) and the valley of the Rio San Francisco (Fig. 1c).

The dataset used in this study includes 452 NOAAAVHRR scenes (NOAA 12, 14, 15, 16, 17; $1 \mathrm{~km}^{2}$ Local Area Coverage [LAC] data) acquired during 2002 and 2004 at a High Resolution Picture Transmission (HRPT) receiving station. The station is operated in the framework of the Marburg Satellite Station (Bendix et al. 2003b) at the headquarters of the Ecuadorian weather service INAMHI in Quito. Sixty-two percent of the data comprises daylight images, including the solar bands (AVHRR 1 and 2) required for optical and microphysical cloud property retrieval (e.g. cloud optical depth, LWP). Thirty-eight percent is night imagery providing infra-red spectral bands (AVHRR 3 to 5) only. Standard preprocessing of the data includes calibration and geocorrection to the UTM map projection (e.g. Bachmann \& Bendix 1992, Bendix \& Bachmann 1993). Preprocessed data are stored in the research group data base (Göttlicher \& Bendix 2004). Cloud classification (day and night) for every image is performed by means of a specific cloud detection scheme. The procedure is described in Bendix et al. (2004). The implementation of the scheme includes the calculation of cloud-top height using an approach modified after Saunders (1988). The method for obtaining LWP is described in Stephens et al. (1984) and Bendix (1995). It should be stressed that only a subset of the NOAA data set (371 images) could be used for processing because the scheme makes use of NOAA channel 1 $(0.58-0.68 \mu \mathrm{m})$, which is available during daytime only and because the accuracy of the calculation significantly decreases at higher solar zenith angles $\left(>80^{\circ}\right.$, Bendix 1995), thus excluding images close to sunrise or 

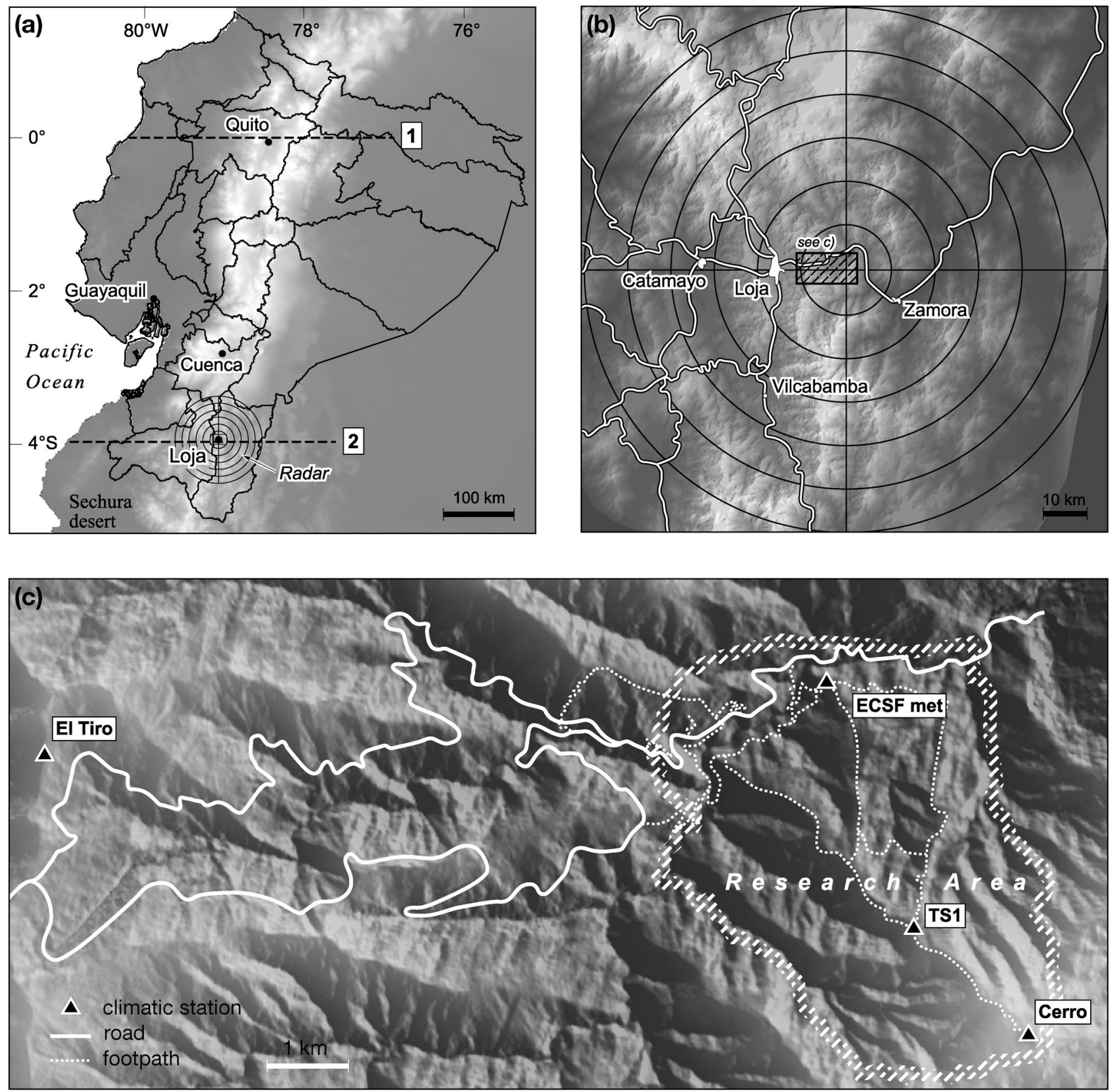

Fig. 1. Study area. (a) Ecuador and adjacent areas (for profile lines 1 and 2 see Figs. 4, 9 \& 12), (b) wider study area of the special research group FOR402, (c) central study area of the special research group FOR402 in the vicinity of the ECSF (Estación Científica de San Francisco) station building and the valley of the Rio San Francisco

sunset from the calculation. The original parameterization scheme by Stephens (1978), which is the basis of the retrieval method, is based on radiative transfer calculations for different water clouds. As a result, the calculated LWP for ice clouds refers to a water cloud with an equal spectral albedo. Consequently, this restriction of the scheme must lead to a slightly distorted estimate of the real amount of condensate in ice clouds. Maps of cloud frequency have been derived by the aggregation of all binary cloud masks $(0=$ pixel free of clouds , $1=$ pixel cloud-covered) for the relevant period (day, night, year, season) for each pixel. The resulting map is then divided by the number of images used and multiplied by 100 in order to derive relative frequencies. NCEP reanalysis wind data (www.cdc.noaa.gov/ncep_ reanalysis) are used to illustrate the interaction of atmospheric flow, topography and cloud formation. The seasonal wind fields for the surface and the 850 hPa levels (see Fig. 2) are calculated by averaging the monthly means from 1968-1996. 


\section{DJF}

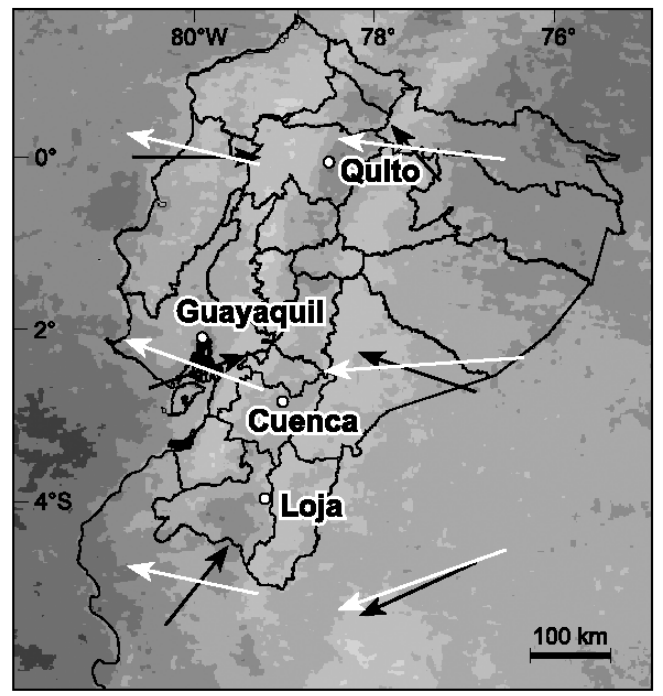

MAM

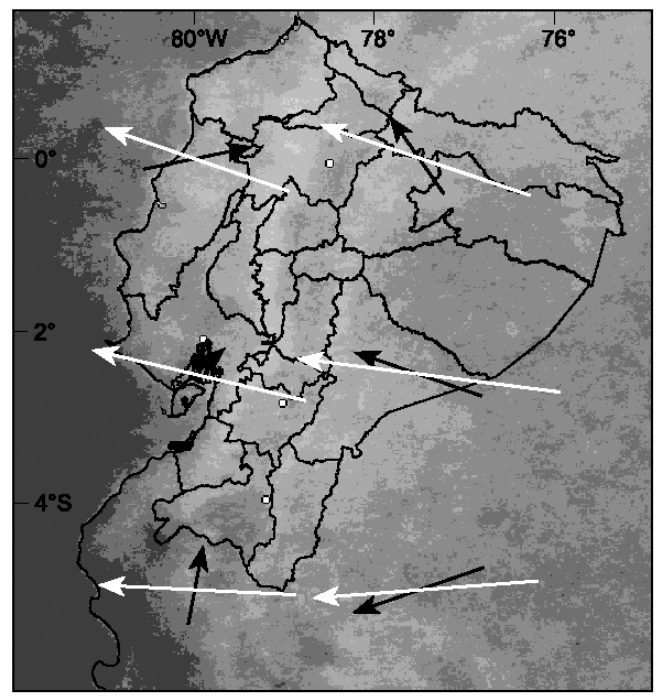

JJA

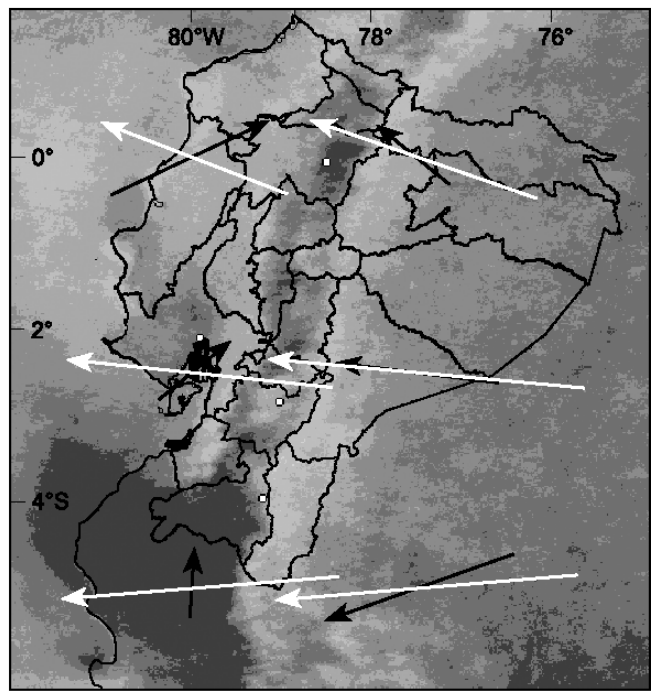

\section{SON}

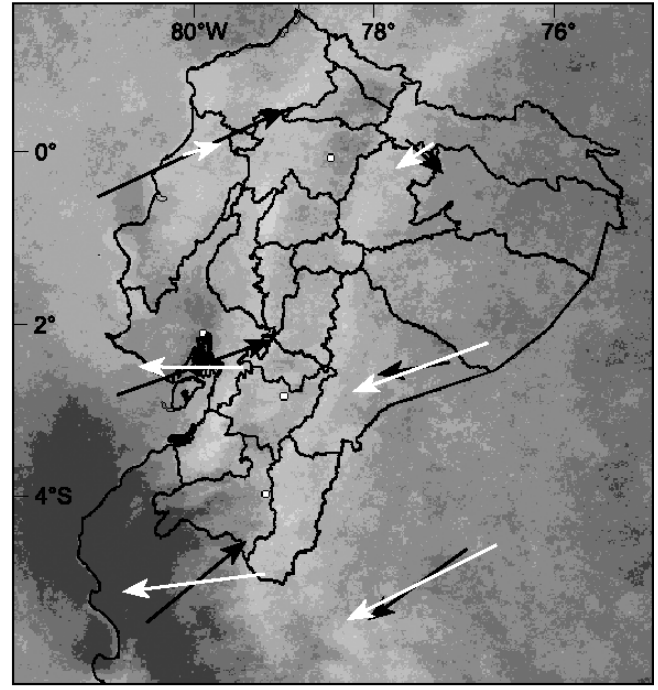

Frequency [\%]

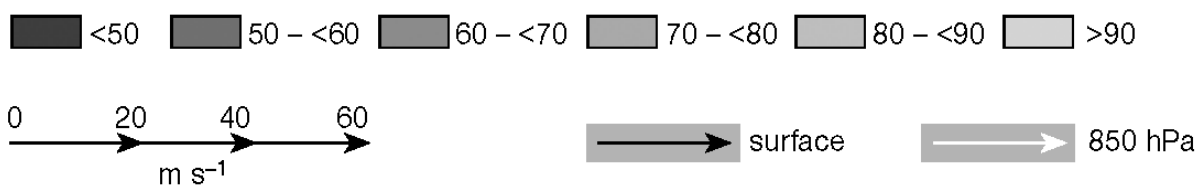

Fig. 2. Seasonal cloud frequencies for Ecuador and adjacent areas. Seasonal wind fields for surface and $850 \mathrm{hPa}$ levels are calculated from NCEP reanalysis data

\section{RESULTS}

\subsection{Cloud frequency}

Fig. 2 illustrates the seasonal frequency of cloudiness as derived from the entire data set. For most parts of the study area, the highest cloud frequency is obtained in austral summer December/January/February (DJF). This time of the year is the main rainy season in most of
Ecuador (Bendix \& Lauer 1992) which explains the increased cloud frequency. High cloud amounts are detected for the coastal plain of Ecuador and the southern part of the Amazon region. Lower frequencies occur in the inter-Andean basins, which show a patchy structure of cloudiness due to topographical effects as described by Bendix \& Rafiqpoor (2001) and Sklenár̆ \& Lægaard (2003). Reduced frequencies are also found over coastal waters, especially those off the north- 


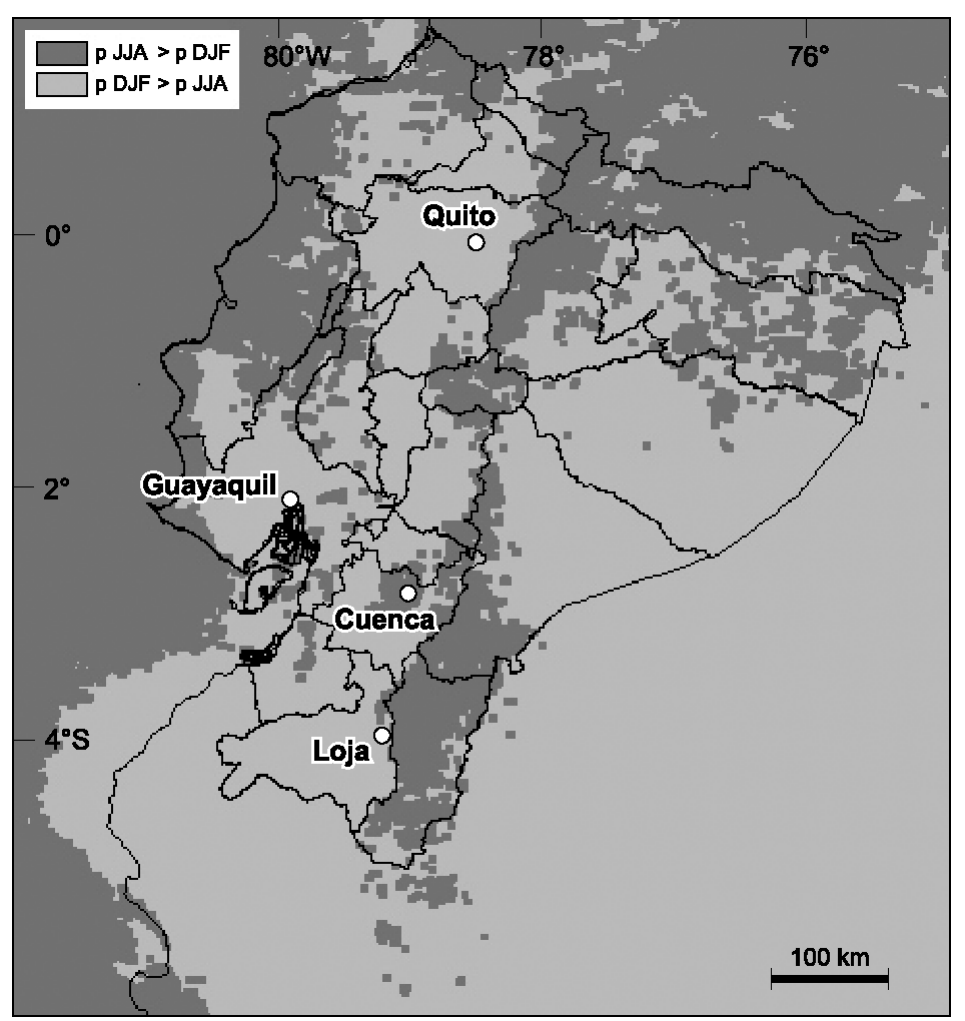

Fig. 3. Comparison of cloud frequency (p) between austral winter (June/July/August, JJA) and summer (December/January/February, DJF)

Peruvian coast (Sechura desert), as well as over the northern part of the Amazon. Bands of high cloud frequency running parallel to the Andean chain on the western and eastern Andean slopes (more pronounced on the latter) are a striking spatial feature. The eastern band is also detected in satellite-based rainfall maps and marked as the Andes-occurring System (AOS) (de Angelis et al. 2004a).

Generally, the high cloud frequencies are the result of barrage effects on the windward side of the Andes. Moist Amazon airmasses are lifted to condensation with the well-developed easterlies (see Fig. 2 for wind field) throughout the year. Even a smooth stable ascent of air masses regularly leads to condensation and cloud formation in this area (see Kirshbaum \& Durran 2004 for stable ascent hypothesis) and produces relatively shallow orographic cap clouds.

The less pronounced western cloud band forms as a result of a combined sea/upslope breeze system during the day. This circulation system is characterised by moist westerly winds in the lower part of the troposphere (e.g. Bendix 2000) which cause cloud formation on the western Andean slopes.

In contrast, cloud frequencies in austral winter June/July/August (JJA), the major dry season in the coastal plains and the western and central highlands, are generally lower. However, the Pacific area off the coast of northern and central Ecuador reveals a significant increase in cloudiness, while the coastal waters off northern Peru exhibit a weak decrease. The area of minimum cloudiness now extends from the coastal waters of northern Peru to the Sechura desert and the highlands of southern Ecuador to the basin of Catamayo. Additionally, the patchiness in the interAndean basins is more pronounced, with a distinct minimum in the area of Quito and in the valley of the Rio Guayllabamba north of the capital. The cloud bands along the eastern Andean slopes are well established in this season, coinciding with the main rainy season in altitudes between $\sim 1000$ and $3500 \mathrm{~m}$ a.s.l. This is a unique regime for Ecuador (see Bendix \& Lauer 1992 for an explanation of the dynamics of this regime).

Fig. 3 presents a comparison between cloudiness in austral summer and winter. The map is based on the difference of cloud frequencies (p) during austral winter (JJA) and austral summer (DJF), and clearly illustrates the increased frequencies in the region of the AOS and the marine part of the study area. The austral autumn March/April/May (MAM) is characterised by a reduced cloud frequency in the coastal waters and a reduction of topographical effects in the inter-Andean basins. The cloud bands are less distinct. The spatial pattern in austral spring September/October/November (SON) resembles the winter situation but the topographical effects in the highlands are significantly reducedmost likely as an effect of the onset of the secondary rainy season. The increase of marine cloud frequency south of $>6^{\circ} \mathrm{S}$ latitude is of interest. Cloudiness increases over the cold coastal waters (cold upwelling) particularly, as a result of a rising frequency of coastal fog and low stratus in this season (Bendix \& Lauer 1992, Cereceda et al. 2002).

Fig. 4 shows cloud frequency along 2 altitudinal transects over the Andes in north-central (Quito) and southern (Loja) Ecuador for both day (08:00 to 22:00 h local time [LT]) and night (22:00 to 08:00 h LT). Noteworthy are the topographical effects produced by the mountain chains which shelter valleys and basins from cloud formation on the windward side. This leads to a clear reduction of cloudiness in the inter-Andean basin, which divides the mountain ridges of the west and east Cordillera (see Fig. 4, Quito profile). However, a lee effect is also visible on a smaller scale. One example is the coastal cordillera in the Quito profile causing a slight reduction of cloudiness especially during day- 


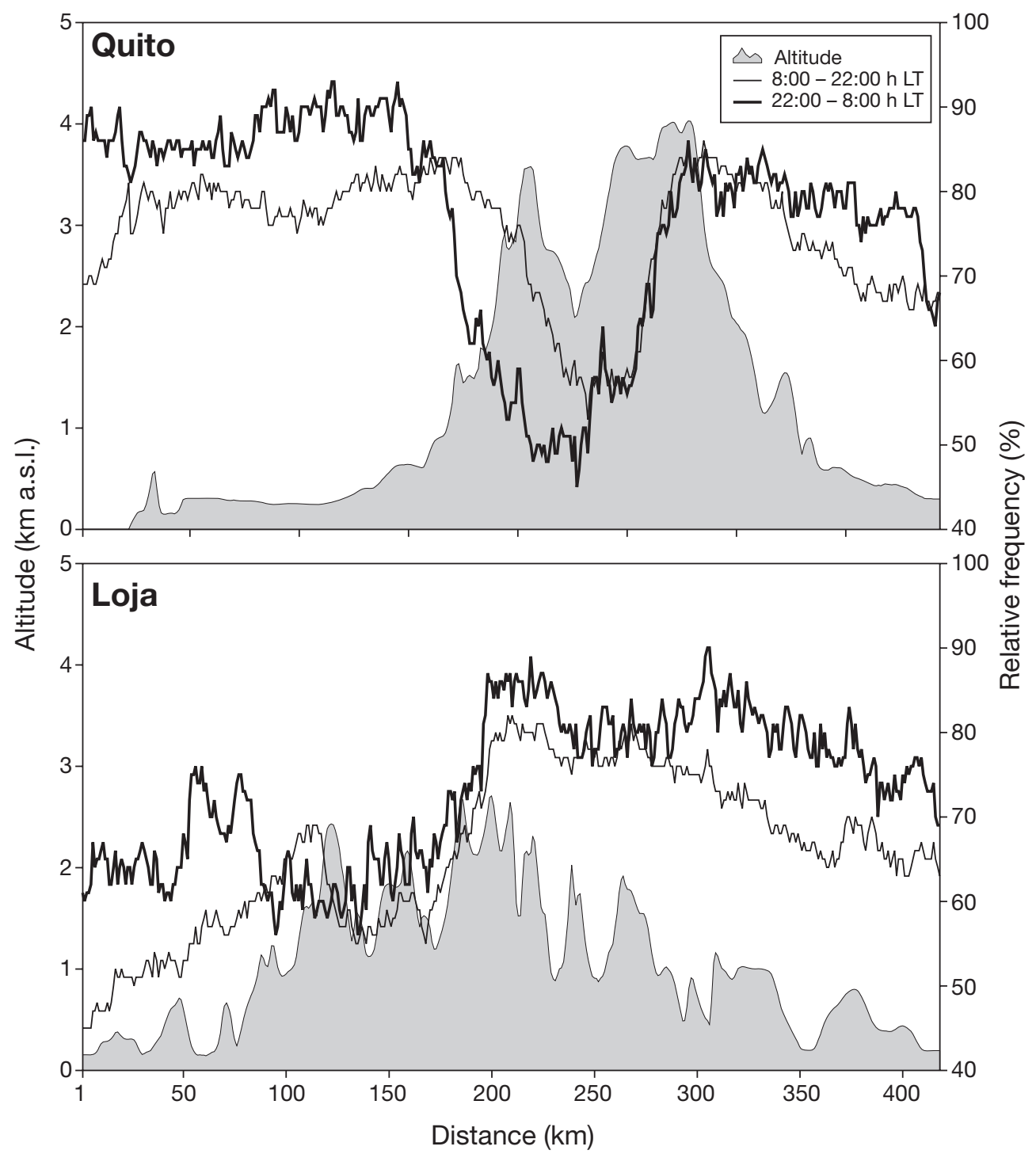

Fig. 4. Cloud frequency profiles for day and night (altitudinal transects as indicated in Fig. 1). LT: local time

light in the lee of the low level westerlies (sea-breeze). The lower pre-Cordillera chains in the southern Ecuadorian Amazon (Loja profile, e.g. at $360 \mathrm{~km}$ ), where cloudiness is reduced on the western lee side with reference to the well developed easterlies, are another example. The windward sides, on the other hand, generally show an increase in cloud frequency.

Fig. 4 also illustrates the difference of cloudiness between day (08:00 to 22:00 h LT) and night (22:00 to 08:00 h LT). Nocturnal cloudiness is increased at the eastern Andean slopes and the Amazon foothills in both profiles, and this agrees quite well with the observation of de Angelis et al. $(2004 \mathrm{a}, \mathrm{b})$ that the AOS is most strongly established during the night, due to the katabatic outflow from the Andes. This outflow causes cold front dynamics (with raining clouds) when it converges with the relatively warm Amazon air masses in this region. The altitudinal zone between 1800 and $4000 \mathrm{~m}$ a.s.l. reveals the clearest effect in both profiles, with regional differences in cloud frequency for highland areas. While the eastern part of the inter-Andean basin in central Ecuador (Quito profile) is characterised by similar cloud occurrence during day and night, the western Cordillera chain shows a significant maximum during the day which is mainly due to thermal breeze effects. This feature is only weakly developed in southern Ecuador (around $100 \mathrm{~km}$ in the Loja profile) because the western Cordillera is not well established in this area. In particular, the smaller basins (e.g. at 140, $175 \mathrm{~km}$ ) reveal a nocturnal cloud frequency maximum that is most likely due to cold air drainage flow, which frequently produces low level stratus clouds in the 


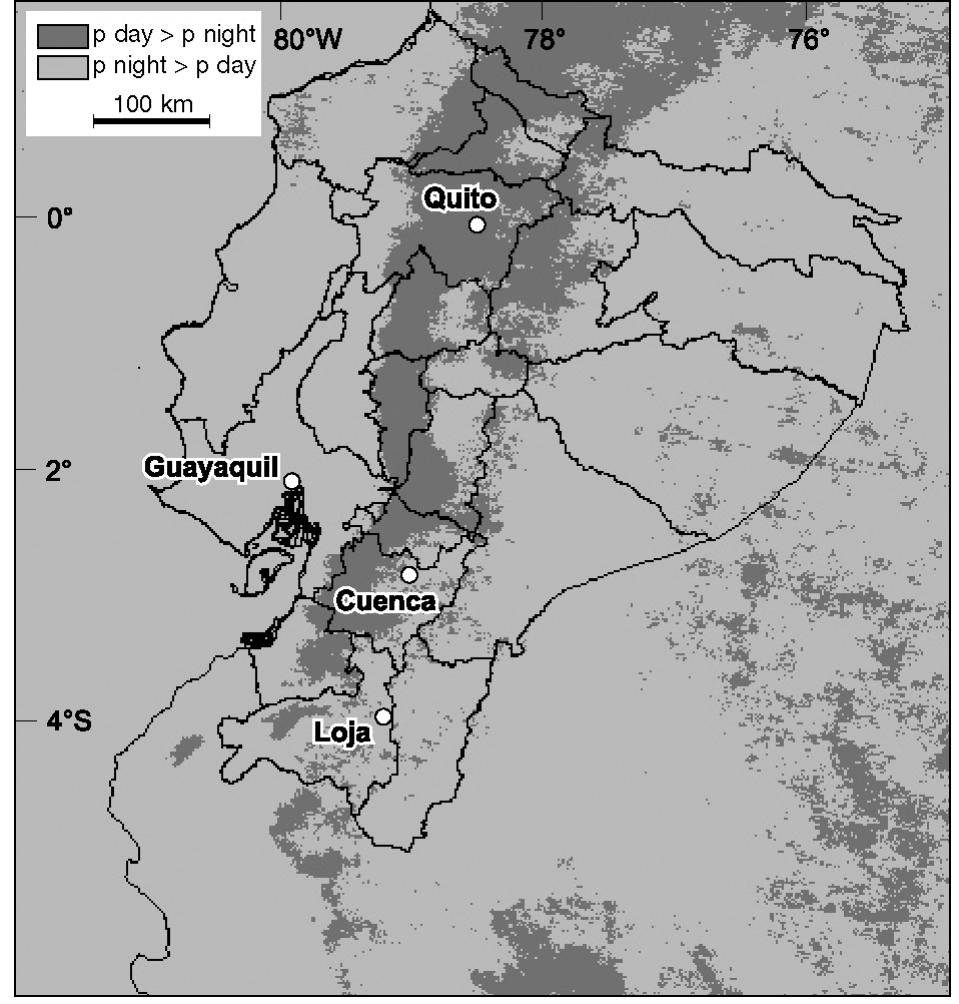

Fig. 5. Comparison of cloud frequency (p) between day and night

The first zone comprises the stations of Catamayo, Loja and Vilcabamba (Fig. 6). This area west of the main Cordillera is characterised by a maximum of cloud frequency from January to April, and a secondary maximum centred around October/November $(\mathrm{ON})$. Minimum cloud frequency is observed from May to July. This seasonal behaviour is in general agreement with the occurrence of the rainy seasons in the highlands of Ecuador, which is mainly linked to the annual course of solar irradiance (Bendix \& Lauer 1992). However, regional modifications in average cloud frequency can be observed. Relatively low values occur in the basin of Catamayo with generally drier conditions as indicated by an increase of drought-tolerant xeric plants (Richter 2003). This is due to a greater distance to the Pacific and Amazonian moisture pools and distinct lee effects. The same cloud regime with increased frequencies is observed for the stations Vilcabamba and Loja, which are still in the lee of the main Cordillera and hence sheltered from the well developed trades especially in JJA (cf. average windfield in Fig. 2), while closer to the Amazonian moisture pool. In some cases, cloud frequency increases with height (Fig. 6,

morning hours (Lauer et al. 2003). The coastal plain is also characterised by a clear nocturnal peak of cloudiness.

The spatial distribution of the diurnal course of cloudiness is presented in Fig. 5. The map is based on the difference of the annual average cloud frequency for all available daytime images ( $p$ day) and all available nighttime images ( $p$ night). Nocturnal maxima in the Amazon, the coastal plain and the Pacific area can be observed (as already confirmed in the profiles). As expected from the dynamics of the AOS, the nocturnal maximum in the Amazon partly changes to a maximum during daylight towards the Andean mountains. The situation for the highlands seems to be more complex. The maximum cloudiness during the day can be generally observed for the western Cordillera and partly for the highlands and the eastern Cordillera (especially in the northern/central part of Ecuador), but some isolated nocturnal maxima also occur in these areas, especially in the greater inter-Andean basins, e.g. at Ibarra in the north, and in the central basin from Machachi to Riobamba.

Cloud values of the central study area in southern Ecuador reveal the complexity of cloud occurrence at the local scale (Fig. 6). Three major zones of different seasonal courses can be distinguished for the central study area.
Vilcabamba $<70 \%$, Loja $>70 \%$ ), mainly due to a decrease in the sheltering effect and an increase in cloud formation caused by heating effects in the basins and resulting convection on the bordering slopes, triggered by the up-slope breeze system (Weischet 1969).

The transition zone between the cloud regimes west and east of the main Cordillera is marked by the station pixels of El Tiro and Cajanuma (Fig. 6). The typical dry season in austral winter (JJA) disappears while a third peak of cloud frequency in June/July (JJ) occurs. This change is already apparent at the pixel of the station El Tiro (Fig. 6), defining the mountain pass separating the eastern Andean slopes from the basin of Loja, and is clearly established for the station Cajanuma on the crest of the main Codillera.

The third regime is specific to the Amazon-exposed part of the study area and includes the pixels for the meteorological stations ECSF, Zamora, TS1 and Cerro del Consuelo (Fig. 6). Cloud frequency is high throughout the year, especially for the higher terrain (TS 1, Cerro). This is mainly due to continuous barrage effects of the well-developed trades (cf. Fig. 2 for the wind field) which favours condensation and cloud formation at the windward sides of the Cordillera ridges. Additionally, the thermal up-slope breeze system generally causes higher cloud frequencies at the bordering slopes of valleys and basins. The lower stations (ECSF, 
Zamora), on the other hand, reveal slightly reduced frequencies and a greater variability throughout the year, which is due to the reversal of the valley breeze system which causes a descending branch over the valley/basin centre with cloud clearance and/or local lee effects.
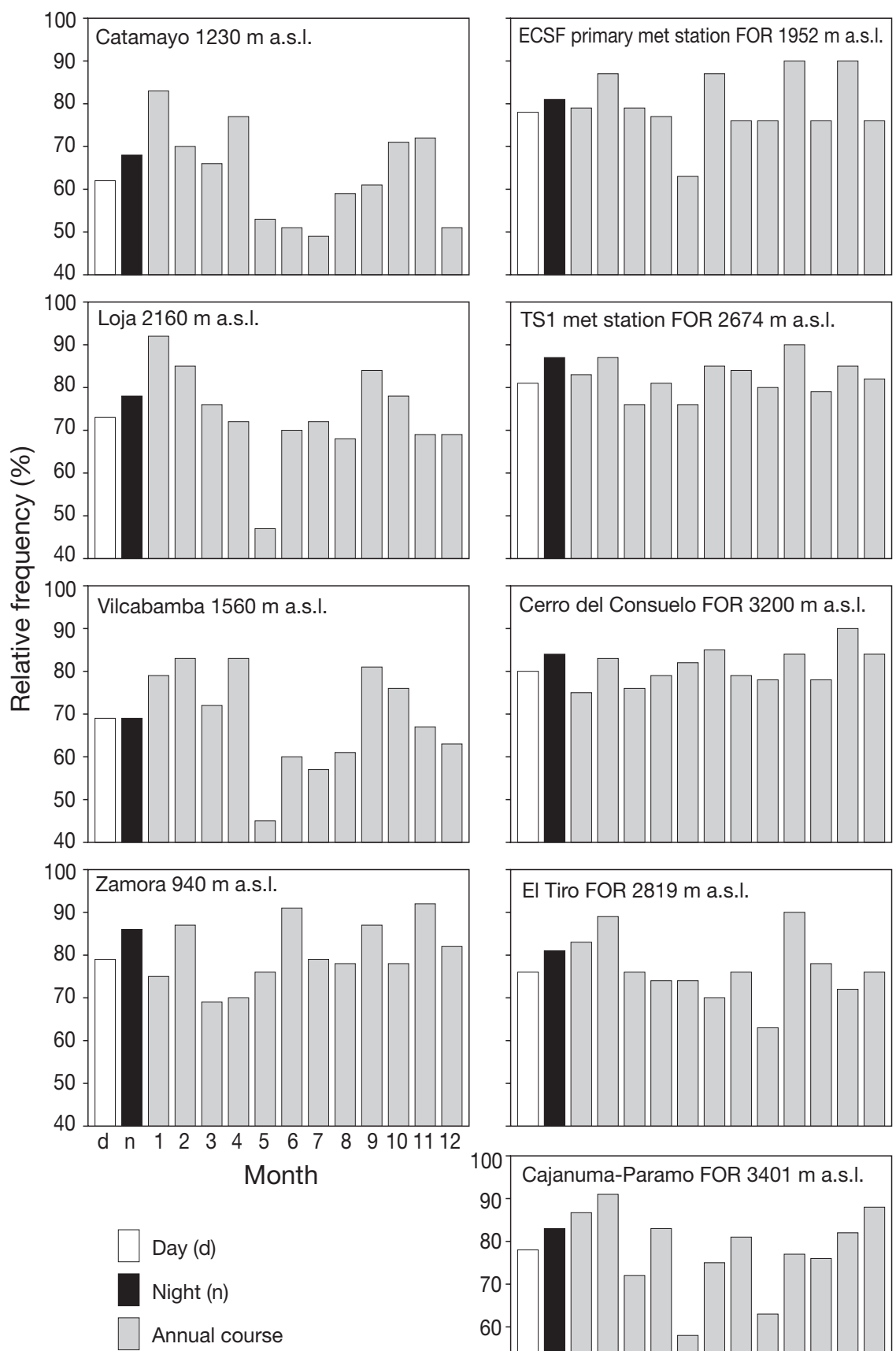

Annual course
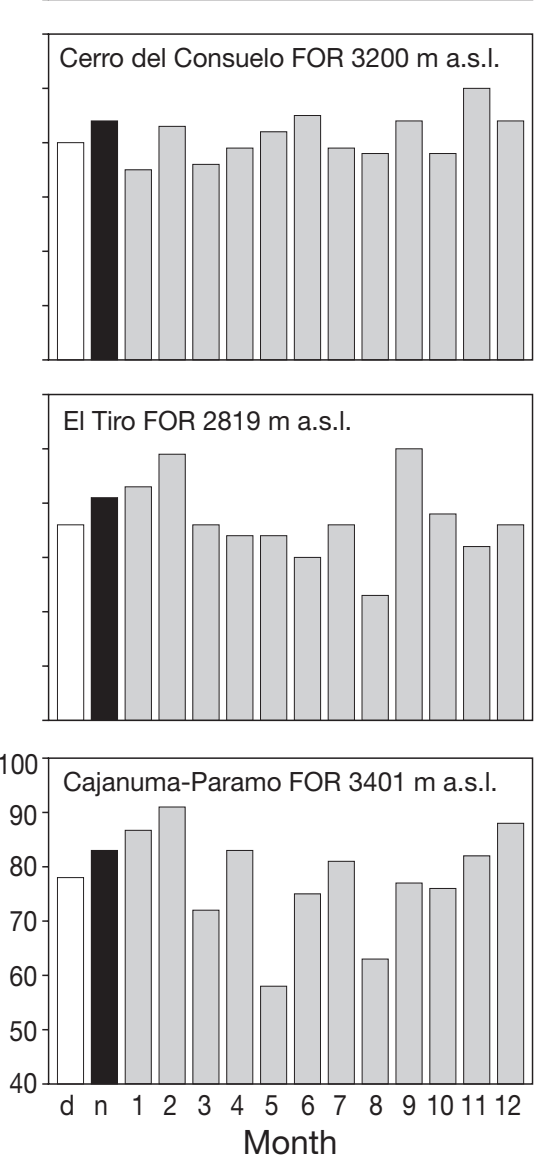

Fig. 6. Cloud frequency (diurnal and annual course) in the central study area

\subsection{Cloud-top height}

Average cloud-top height is a good indicator of cloud type and can help interpret the cloud frequency maps. The seasonal top height map (Fig. 7) shows that the western Cordillera chain is a major borderline between Pacific and Amazonian climatic influences. Over all seasons, mean cloud-top height is significantly greater east of the western Cordillera, which points to a more convective system in the Amazon in comparison to the coastal plains and the Pacific part of the study area. However, there is a clear seasonal difference for the coastal waters and the coastal plains of Ecuador, due to a change in cloud formation mechanisms.

The greatest top height values are found during the second part of the main rainy season (Fig. 7, MAM), which, together with the greater spatial patchiness, points to higher convective activity. Where sea surface temperature increases, deep convective clouds with high top-heights dominate, increasing the average top height, but resulting in patchy top-height patterns. Lowest average top height values $(<3 \mathrm{~km})$ are most frequently found during the coastal dry season in austral winter (Fig. 7, JJA). Cold water upwelling related to the Humboldt current is intensified especially off the coast of southern Ecuador. When the SE-Pacific anticyclone is at its northernmost position this leads to stable conditions of the boundary layer, thus favouring the formation of low stratus cover over the coastal waters and in the coastal plains.

Greatest average top heights are observed during MAM and SON in the Amazonian parts of Peru and Colombia with values of over $8 \mathrm{~km}$. The greatest top height at the eastern Andean slopes of Ecuador occurs outside austral winter. During JJA, average cloud height is generally lower over the whole of Ecuador.

Of interest is also the diurnal change of average cloud-top height, illustrated in Fig. 8. On average, there is no difference for the Pacific area, but there are significant changes for the Amazon area of Ecuador. While 


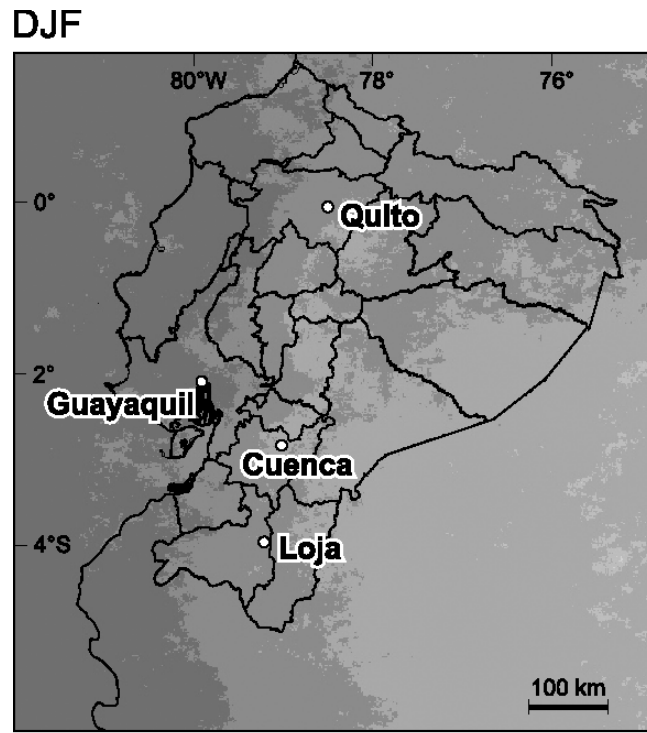

MAM

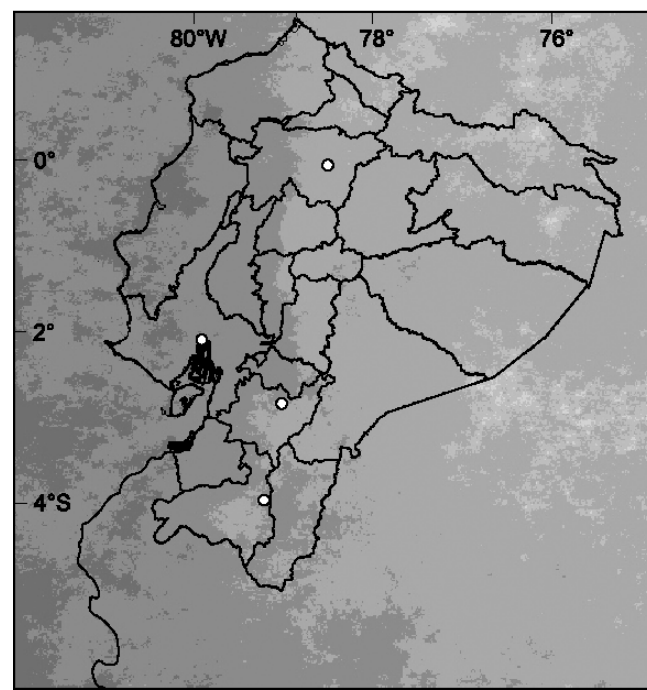

JJA

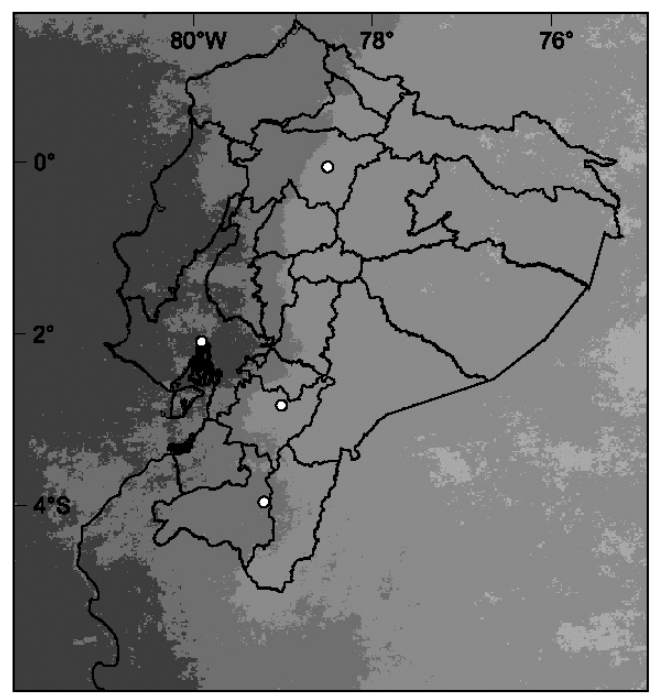

\section{SON}

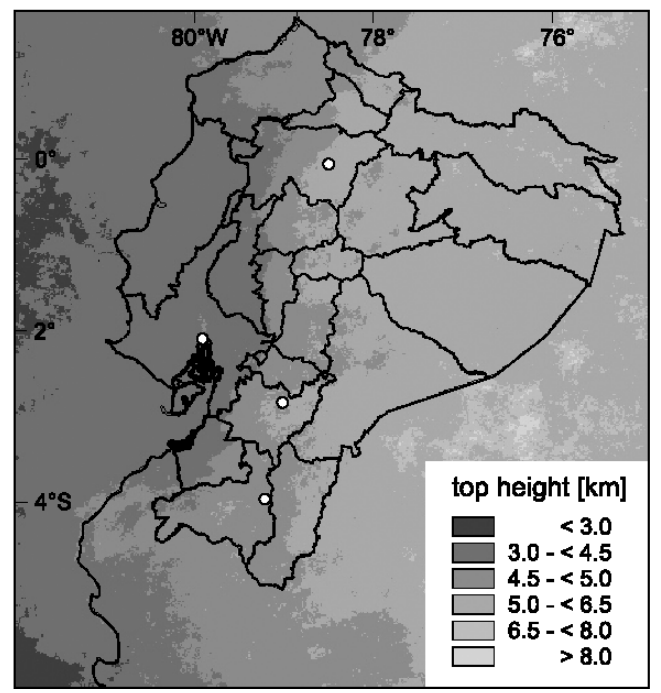

Fig. 7. Seasonal average of cloud-top height for Ecuador and adjacent areas

greater top heights occur over the Amazon and parts of the eastern Andean slopes as well as the inter-Andean basins (e.g. Quito) during the day, average top height decreases during the night (22:00 to 08:00 h LT).

Details of diurnal cloud-top height dynamics for the zonal transects for central and southern Ecuador are shown in Fig. 9. Average top heights are generally greater during the day over the Amazonian part of central and southern Ecuador. The increased variability for this region-which is also generally known for its more continental diurnal course of precipitation (de Angelis et al. 2004b) - points to a more convective regime during the day. In contrast, the area of the AOS at the eastern Andean slopes is characterised by relatively low variability in average cloud-top height. This means that the formation of cloudiness is little influ- enced by the diurnal cycle of radiation, but is influenced by dynamic effects on windward slopes.

The conditions in inter-Andean basins (Fig. 9, Quito profile) resemble those of the Amazon area. Cloud-top height in this mountainous area is significantly greater during daylight and clearly reduced at night. This indicates a diurnal change in cloud formation processes. Solar heating and thermal breeze systems cause the formation of convective clouds during daylight. The resulting cumuliform clouds generally have greater cloud top heights. During night, cold air drainage flow from the bordering slopes of the inter-Andean basins leads to a stable stratification in the basins. The dew point temperature is reached by continuous cooling in the early morning hours, resulting in the formation of ground fog and low level stratus with low cloud tops 
(Lauer et al. 2003). However, variability is significantly enhanced over this area and the adjacent western Cordillera chain. While variability is generally enhanced in the inter-Andean basin at Quito day and night, the western Cordillera chain shows an increase in variability for the evening/night period only. This is most likely due to thermally-driven convective systems which can last until the early evening hours during the main rainy season, in comparison to lower cloud decks during the dry season.
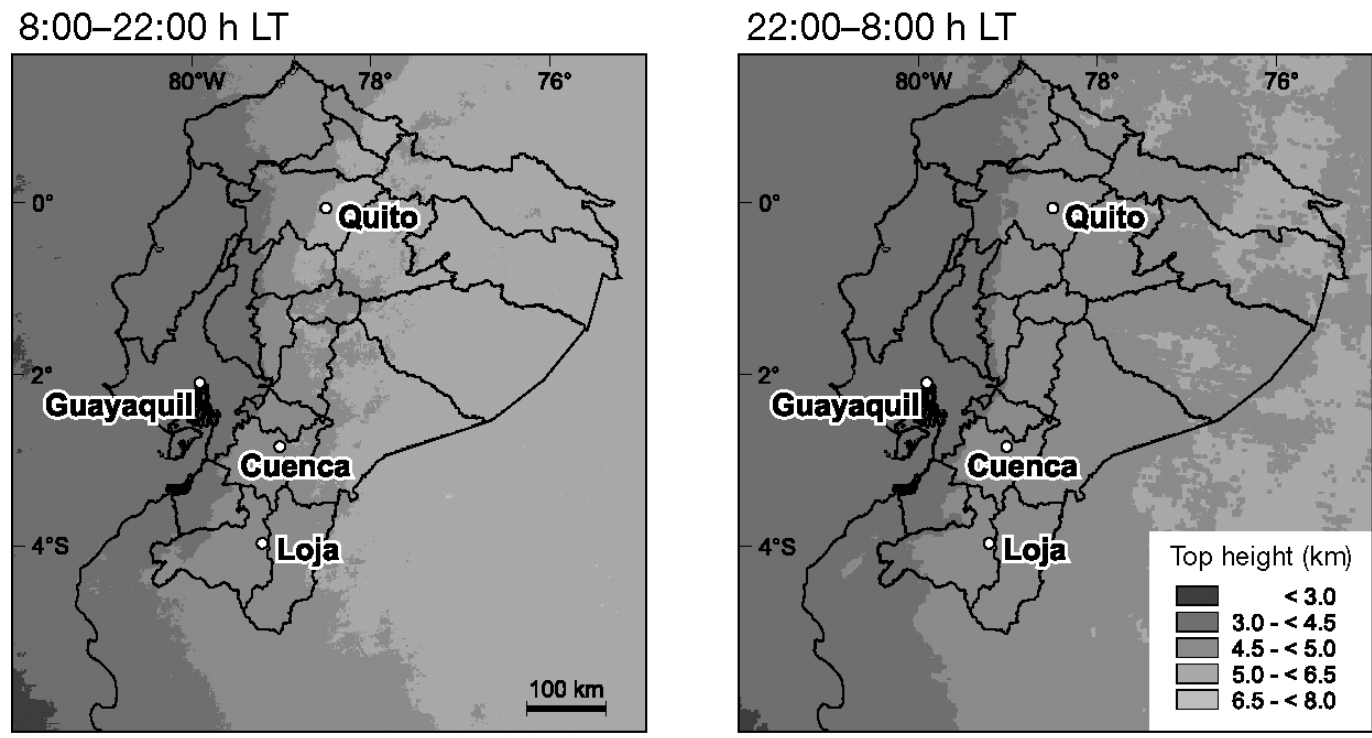

Fig. 8. Cloud-top height during day and night. LT: local time
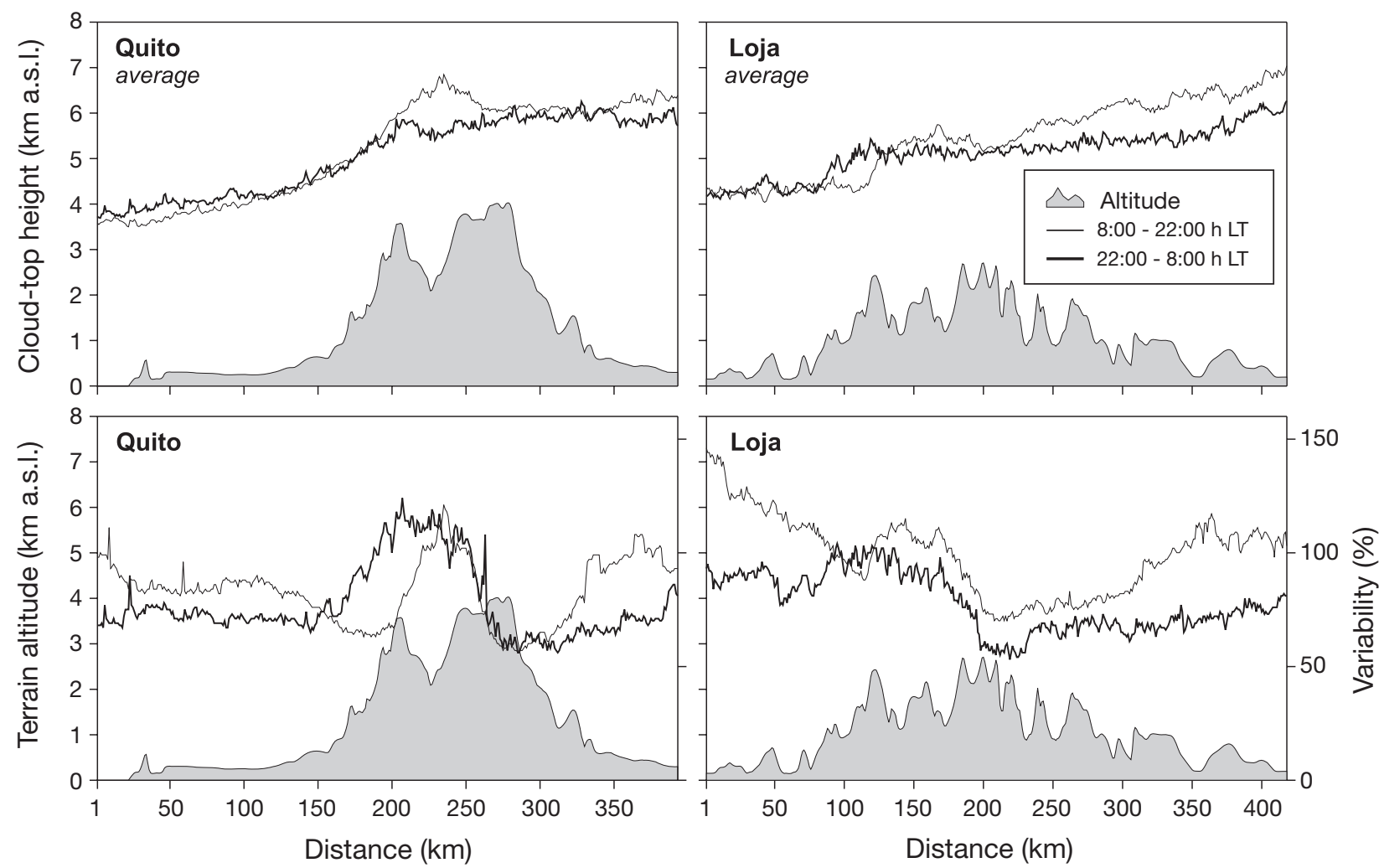

Fig. 9. Zonal profiles of average cloud-top height during day and night (altitudinal transects as indicated in Fig. 1). LT: local time 
The seasonal structure in the central study area confirms the close relation between rainfall zonation, topography and average top height (Fig. 10). The 2 rainy seasons (JFM, ON) show the greatest average top heights at all station pixels in combination with an enhanced standard deviation. The lower average top height of the cloud and rain maximum which normally occurs during JJ (Bendix \& Lauer 1992; see also Fig. 6) at the eastern Andean slopes (Zamora), the ECSF area (ECSF, TS1, Cerro) and the crest area of the main Cordillera (Cajanuma) means that enhanced cloudiness and rainfall is generally related to lower cap clouds, partly with embedded shallow convection, and characterised by a relatively low variance in height.

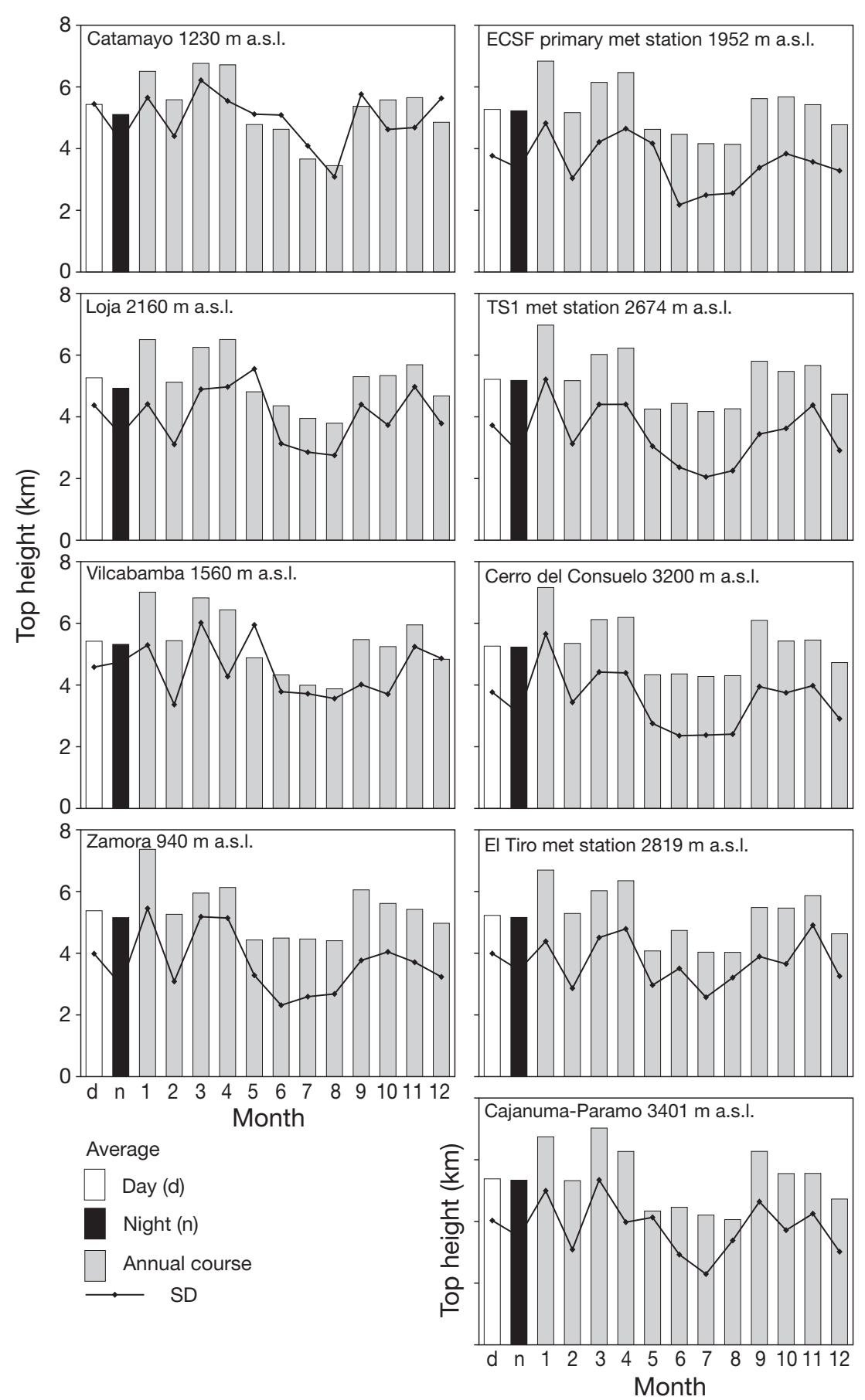

Fig. 10. Average cloud-top height and standard deviation (SD) (diurnal and annual course) in the central study area

\subsection{Cloud optical depth and LWP}

Cloud optical depth is the columnar value of extinction, and LWP is the columnar value of liquid water content (LWC) from cloud base to cloud top. Hence, both are also a function of cloud geometrical thickness (e.g. Reudenbach \& Bendix 1998). Fig. 11 presents maps of the annual average optical depth and LWP derived from all available NOAA daylight images with sufficient illumination (see 'Section $2^{\prime}$ ).

Cloud optical depth and LWP are significantly enhanced in the Amazon area. This is most likely an effect of the greater vertical extension of mainly convective clouds. In contrast, the low average values of optical depth and LWP over the Pacific area and the coastal plains illustrate that cloudiness is frequently characterised by a lower stratus layer with a restricted vertical extension. Even if LWP is low, clouds may, nevertheless, have a high LWC, especially in marine environments. Over the Andes a patchy structure of moderate optical depth and LWP values can be observed where some basins (e.g. east of Quito) reveal relatively low values, indicating a high probability of shallow stratus layers due to continental fog/low stratus formation in the morning hours (Lauer et al. 2003; see also 'Section 3.2').

Fig. 12 illustrates the seasonal variation of cloud optical depth $(\tau)$ and LWP for southern Ecuador. A clear difference can be observed for the coastal areas. Values are high for the main/ terminal phase of the rainy season (MAM), mainly due to a greater vertical extent of the dominating convective clouds. In contrast, low values can be observed during austral winter 

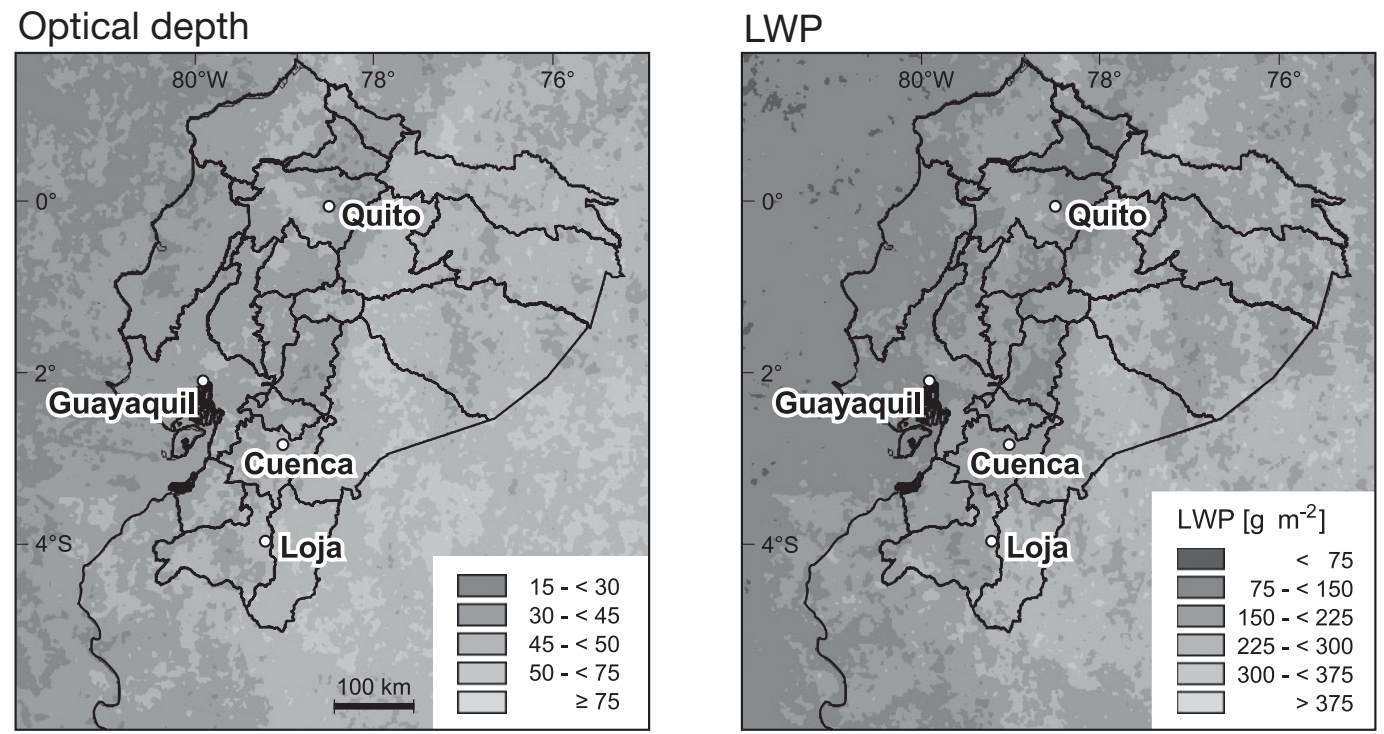

Fig. 11. Annual average optical depth and liquid water path (LWP) for the entire study area

(JJA), characterised by the dominance of low and relatively shallow stratiform clouds in this region. The values change at the western escarpment of the Andes (around $100 \mathrm{~km}$ of the profile) where average optical depth and LWP are enhanced in austral winter (JJA). This could be an indication for an enhanced up-slope breeze system causing higher intensities of highreaching convective clouds. The highest values are generally found in the Amazon area and the lowest in the inter-Andean basin area for both seasons. However, at the eastern slopes of the Andes a clear difference exists between the windward sides with high values of cloud optical depth and LWP, and lee sides with low values during MAM. The spatial variability is significantly reduced during austral winter (JJA). A general increase in cloud optical depth and LWP towards the Amazon is characteristic in this area.

\section{SUMMARY AND CONCLUSIONS}

The present study reveals features of cloud occurrence in Ecuador on several scales. Seasonal cloud frequency is generally linked to the seasonality of rainfall. However, external factors like cold water upwelling off the coast of Ecuador/northern Peru and the complex topography of the Andes with its dynamic effects on the windward and lee sides of the mountains can significantly modify (increase/decrease) cloud frequency. The comparison of day and night frequencies in particular shows that in some areas cloud cover is more a result of larger-scale stream-flow effects (e.g. a barrage effect of the easterlies at the eastern Andean slopes in the area of the AOS), while smaller-scale sys- tems such as thermal breezes mainly influence the course of cloudiness in other regions (e.g. western Cordillera). The results from the central study area are of special importance for ecologists. The valley of the Rio San Francisco and adjacent areas has distinct conditions, with high cloudiness throughout the year and an increase of cloud frequency with terrain height. This is likely to have ecological implications (such as for plant phenology; see 'Section 1') that are distinct from those of the area west of the main watershed.

Cloud-top height values reveal a clear division between the area with Pacific influence, bordered by the western Cordillera chain, and the eastern part of the study area. Average cloud-top height generally increases from west to east, which points to more stratiform cloud dynamics in the Pacific area and the coastal plains, and more convection with higher variability in the Amazon region. However, regional differences have to be considered. Low variability in cloudtop height over the year, for instance at the eastern Andean slopes (in the area of the AOS), points to cloud formation under more stable conditions due to barrage effects of the easterlies. This results predominately in cap clouds, possibly with embedded shallow convective structures. For the central study area the difference between cloudiness levels during the main rainy seasons (JFM, ON) and for JJ is essential. While greater cloud-top heights during the rainy seasons point to more convective activity, winter is clearly characterised by lower top heights with decreased variability. This underlines a more stratiform character of cloudiness in JJ.

Cloud optical depth and LWP, which partly depend on cloud geometrical thickness, are higher over the 


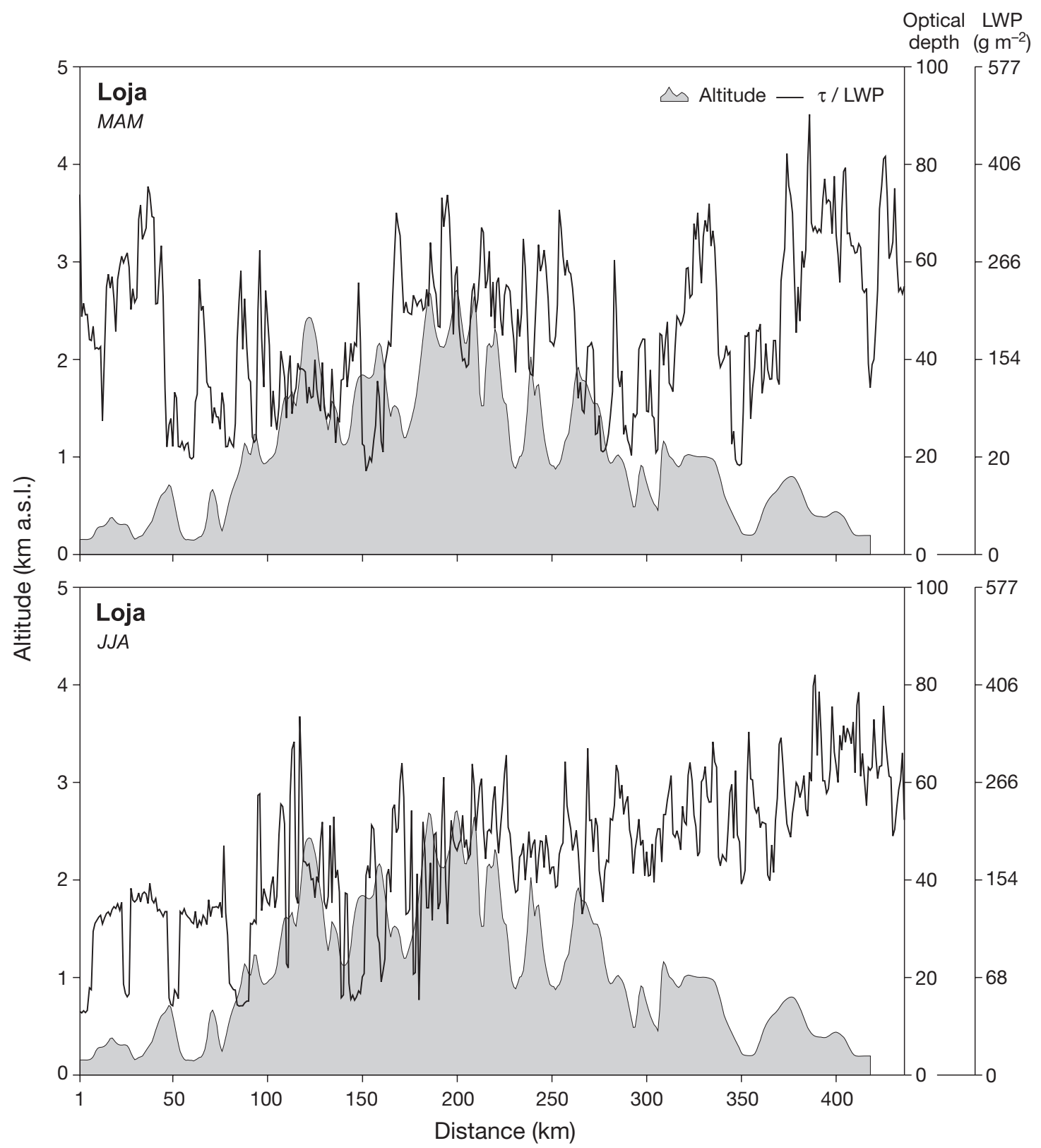

Fig. 12. Seasonal average of optical depth $(\tau)$ and liquid water path (LWP) in southern Ecuador (altitudinal transects as indicated in Fig. 1). MAM: March/April/May; JJA: June/July/August

Amazon area than in the Pacific region. This is mainly a result of convective activity over the Amazon, i.e. more moisture is transformed into a liquid state in the atmospheric water cycle over this area. In comparison to the coastal plains and the offshore area of southern and central Ecuador, convective activity over the Amazon is high throughout the year. This is mainly due to the influence of the SE-Pacific anticyclone and the cold water upwelling of the Humboldt current on the Pacific area of Ecuador in austral winter. This leads to a more stable stratification of the lower troposphere, and favours shallow boundary-layer stratus clouds with a reduced geometrical/optical thickness as well as lower LWP values.

Cloud occurrence and cloud properties are not entirely linked to rainfall dynamics, but the patterns of cloudiness reflect spatio-temporal precipitation anomalies where the rainfall regime is mostly convective, or where orographic rainfall is formed in cap clouds of moderate thickness at the windward sides of the Andes. In areas with a high contribution of low stratiform clouds under stable boundary layer conditions 
(e.g. nocturnal fog/low stratus layers in the interAndean basins or coastal fog/stratus), cloud and rainfall patterns can be significantly decoupled.

Although a 3 yr data set is normally not sufficient to form a cloud climatology, the results give a good overview of cloudiness in the Tropics of Ecuador, aided by the similarity of the tropical climate between years. However, future studies should use a comprehensive data set of GOES imagery, especially for investigations of the diurnal cycle of cloudiness over Ecuador. On the local scale of the central study area, digital photography can be used to investigate the diurnal and seasonal cycle of cloud formation and dissipation with terrain altitude. A study based on a 4 yr data set from a conventional weather observation camera (conventional webcam) with a 5 min temporal resolution, located at the ECSF research station, is currently in progress.

Acknowledgements. The current study was performed within the framework of the DFG Research Group FOR 402 'Functionality in a tropical mountain forest: diversity, dynamic processes and utilisation. Potentials under ecosystem perspectives', and was generously funded by the German Research Council DFG (BE 1780/5-1, 5-2, 5-3). Thanks to NCI (Loja) for logistic support as well as R. Ponce and E. Palacios (INAMHI) for operating the HRPT-receiving station on behalf of the Marburg Satellite Station.

\section{LITERATURE CITED}

Alados I, Olmo FJ, Foyo-Moreno I, Albados-Arboledas L (2000) Estimation of photosynthetically active radiation under cloudy conditions. Agric For Meteorol 102:39-50

Bachmann M, Bendix J (1992) An improved algorithm for NOAA-AVHRR image referencing. Int J Remote Sens 13: 3205-3217

Barry RG (1992) Mountain climatology and past and potential future climatic changes in mountain regions: a review. $\mathrm{Mt}$ Res Dev 12:71-86

Beck E, Müller-Hohenstein K (2001) Analysis of undisturbed and disturbed tropical mountain forest ecosystems in Southern Ecuador. Die Erde 132:1-8

Bendix J (1995) A case study on the determination of fog optical depth and liquid water path using AVHRR data and relations to fog liquid water content and horizontal visibility. Int J Remote Sens 16:515-530

Bendix J (1999) A comparative analysis of the major El Niño events in Ecuador and Peru over the last two decades. Zentbl Geol Paläontol I 7/8:1119-1131

Bendix J (2000) Precipitation dynamics in Ecuador and Northern Peru during the 1991/92 El Niño: a remote sensing perspective. Int J Remote Sens 21:533-548

Bendix J (2002) A satellite-based climatology of fog and lowlevel stratus in Germany and adjacent areas. Atmos Res 64:3-18

Bendix J, Bachmann M (1993) Operationell einsetzbares Verfahren zur Nebelkartierung, Nebelhöhenbestimmung und Bildentzerrung auf der Basis digitaler NOAA/AVHRR Daten. Bonn Geogr Abh 86:11-111

Bendix J, Bendix A (1998) Climatological aspects of the
1991/92 El Niño in Ecuador. Bull Inst Fr Etud Andines 27: 655-666

Bendix J, Lauer W (1992) The rainy seasons in Ecuador and their climatic interpretation. Erdkunde 46:118-134 (in German with English Abstract)

Bendix J, Rafiqpoor MD (2001) Thermal conditions of soils in the Páramo of Papallacta (Ecuador) at the upper tree line. Erdkunde 55:257-276

Bendix J, Gämmerler S, Reudenbach C, Bendix A (2003a) A case study on rainfall formation during El Niño 1997/98 in Ecuador and surrounding areas as inferred from GOES-8 and TRMM-PR observations. Erdkunde 57:81-93

Bendix J, Reudenbach C, Rollenbeck R (2003b) The Marburg Satellite Station. Proc EUMETSAT Meteorol Sat Users Conf, 2-6 September 2002, Dublin. EUMETSAT, Darmstadt, p 139-146

Bendix J, Rollenbeck R, Palacios WE (2004) Cloud detection in the tropics - a suitable tool for climate-ecological studies in the high mountains of Ecuador. Int J Remote Sens 25:4521-4540

Bruijnzeel LA (2001) Hydrology of tropical montane cloud forests: a reassessment. Land Use Water Resour Res 1: $1.1-1.18$

Caldwell MM, Björn LO, Bornman JF, Flint SD, Kulandaivelu G, Teramura AH, Tevini M (1998) Effects of increased solar ultraviolet radiation on terrestrial ecosystem. J Photochem Photobiol B Biol 46:40-52

Cereceda P, Osses P, Larrain H, Farías M, Lagos M, Pinto R, Schemenauer RS (2002) Advective, orographic and radiation fog in the Tapacá region, Chile. Atmos Res 64: 261-271

de Angelis CF, McGregor GR, Kidd C (2004a) A 3 year climatology of rainfall characteristics over tropical and subtropical South America based on tropical rainfall measuring mission precipitation radar data. Int J Climatol 24:385-399

de Angelis CF, McGregor GR, Kidd C (2004b) Diurnal cycle of rainfall over the Brazilian Amazon. Clim Res 26:139-149

Endlicher W (1982) Der Tages- und Jahresgang der Windgeschwindigkeit in den Hochanden Ecuadors. Freibg Geogr Hefte 18:157-168

Fleischbein K, Wilcke W, Goller R, Boy J, Valarezo C, Zech W, Knoblich K (2005) Rainfall interception in a lower montane forest in Ecuador: effect of canopy properties. Hydrol Proc 19:1355-1371

Gasparri E, Tassara C, Velasco M (1999) El fenómeno de El Niño 1997-1999 en El Ecuador. Del desastre a la prevención. Ediciones Abya Yala, Quito

Göttlicher D, Bendix J (2004) Eine modulare Multi-User Datenbank für eine ökologische Forschergruppe mit heterogenem Datenbestand. Z Agrarinformatik 4:95-103

Hamann A (2004) Flowering and fruiting phenology of a Philippine submontane rain forest: climatic factors as proximate and ultimate causes. J Ecol 92:24-31

Kästner M, Kriebel KT (2001) Alpine cloud climatology using long-term NOAA-AVHRR satellite data. Theor Appl Climatol 68:175-195

Kirshbaum DJ, Durran DR (2004) Factors governing cellular convection in orographic precipitation. J Atmos Sci 61: $682-698$

Landívar CB (1977) El clima y sus características en el Ecuador. Instituto Panamericano de Geografia e Historia, Quito

Landívar CB (1989) Analisis y estudios climatologicos en el Ecuador. Instituto Panamericano de Geografia e Historia, Quito

Lauer W, Rafiqpoor MD, Bendix J (2003) Vergleichende Geoökologie der Hochgebirge der nördlichen (Mexiko) und südlichen (Bolivien) Randtropen sowie der inneren 
Tropen (Ecuador). Abh Math-Nat Klasse Akad Wiss Lit Mainz, Vol 1. Steiner, Stuttgart

Reudenbach C, Bendix J (1998) Experiments with a straightforward model for the spatial forecast of fog/low stratus clearance based on multi-source data. Meteorol Appl 5: 205-216

Richter M (2003) Using plant functional types and soil temperatures for eco-climatic interpretation in southern Ecuador. Erdkunde 57:161-181

Rossel F, Mejía R, Ontaneda G, Pombosa R, Roura J, Le Goulven P, Cadier E, Calvez R (1998) Regionalization of El Niño influence on rainfall in Ecuador. Bull Inst Fr Etud Andines 27:643-654

Rossow WB, Mosher F, Kinsella E, Arking A and 7 others (1985) ISCCP cloud algorithm intercomparison. J Climatol Appl Meteorol 24:877-903

Saunders RW (1988) Cloud-top temperature/height: a highresolution imagery product from AVHRR data. Meteorol Mag 117:211-221

Schiffer RA, Rossow WB (1983) The International Satellite Cloud Climatology Project (ISCCP): The first project of the World Climate Research Programme. Bull Am Meteorol Soc 64:779-784

Schütte K (1968) Untersuchungen zur Meteorologie und Klimatologie des El Niño-Phänomens in Ecuador und Nordperu. Bonner Meteorol Abh 9. Dümmler, Bonn

Sklenár̆ P, Lægaard S (2003) Rain-shadow in the high Andes

Editorial responsibility: Nils Chr. Stenseth,

Oslo, Norway of Ecuador evidenced by Páramo vegetation. Arct Antarct Alp Res 35:8-17

Stephens GL (1978) Radiation profiles in extended water clouds. II: Parameterization schemes. J Atmos Sci 35: 2123-2132

Stephens GL (2005) Cloud feedbacks in the climate system: a critical review. J Clim 18:237-273

Stephens GL, Ackermann S, Smith EA (1984) A shortwave parameterization to improve cloud absorption. J Atmos Sci 41:687-690

Stephens GL, Vane DG, Boain RJ, Mace GG and 10 others (2002) The Cloudsat mission and the A-train-a new dimension of space-based observations of clouds and precipitation. Bull Am Meteorol Soc 83:1771-1790

Vuille M, Bradley RS, Keimig F (2000) Climate variability in the Andes of Ecuador and its relation to tropical Pacific and Atlantic sea surface temperature anomalies. J Clim 13:2520-2535

Weischet W (1969) Climatological principles of the vertical distribution of rainfall in tropical mountains. Die Erde 100: 287-306 (in German with English Abstract)

Wright SG, Carrasco C, Calderón O, Paton S (1999) The El Niño southern oscillation, variable fruit production, and famine in a tropical forest. Ecology 80:1632-1647

Zimmerschied W (1958) Vorläufige Mitteilung über die Niederschlagsverhältnisse in Ekuador. Meteorol Rundsch 11:156-162

Submitted: September 9, 2005; Accepted: December 12, 2005 Proofs received from author(s): January 23, 2006 